\title{
The Factors Affecting Income of Go-Jek Drivers in South Tangerang
}

\section{Nazifah Husainah ${ }^{1}$ and Azizatul Munawaroh ${ }^{2}$}

\author{
${ }^{1}$ Universitas Muhammadiyah Jakarta, Indonesia, e-mail: nen0666@yahoo.com \\ ${ }^{2}$ Universitas Muhammadiyah Jakarta, Indonesia, e-mail: munawarohazizatul@gmail.com
}

\begin{abstract}
The develop an online motor cycle in South Tangerang City, especially in GO - JEK. This has resulted in competition between online motorbike drivers, which affects GO - JEK revenues driver. In addition, the income of the drivers is influenced by several factors, namely working hours, education level, age and work experience. The purpose of this study was to determine the factors that influence the revenue of GO - JEK drivers. This research was conducted in the City of South Tangerang with a total sample of 96 respondents. The method used in this study is probability sampling, especially simple random sampling. Data collection is done by questionnaire, interview, and observation methods. The analysis technique used is multiple linear regression. Based on the results of data analysist, it was found that working hours, age, education level, and work experience simultaneously affect the income of GO - JEK drivers. However, partially, the variables of working hours and work experience have a positive and significant influence while the age and education level variables do not affect the income of GO - JEK drivers. To stabilize GO - JEK driver's income, it must be concerned with the age factor because it is a determining factor for a person's physical condition, GO - JEK should also make a strategy to be able to survive in the midst of increasingly fierce competition between other online motor cycle drivers, and the government must provide a clear regulations regarding online motor cycle like GO - JEK.
\end{abstract}

Keywords: working hours, age, level of education, work experience, income.

\section{Introduction}

The population in the city of South Tangerang has increased every year. As was known in 2016 the total population of South Tangerang City was 1,543,209 and increased in 2017 by 1,593,810 people. The increase in population and non-increasing road segments will have an impact on traffic congestion. This is due to population growth which has an impact on the increasing mobility of citizens which results in private vehicle ownership and public transport. The high level of congestion, security and the need for rapid movement is the main reason for the community to choose alternative public transportation that is felt to be more comfortable, effective and efficient.

The development of online transportation services is far more beneficial to society because of the ease of access and a system that is far more transparent and on target. The people of South Tangerang City have switched to more effective and efficient online transportation. Online transportation is transportation-based using apps in a Smartphone through the Google Play Store or the App Store. The way it works is that users of online transportation services (passengers) will order through the online transportation application and the online transportation service or commonly referred to as the driver will pick up where the passenger and driver will deliver it to the destination of the passenger stated in the application.

One of the online transportation service providers that is booming in South Tangerang is GO - JEK, GRAB and Uber. However, many consumers prefer online motor cycle services for reasons of being faster to the destination and not having to face longer traffic jams such as cars. Each company has a name for online motor cycle services such as GO - JEK company, GO - RIDE, while online motor cycle services from GRAB are GRABBIKE and online motor cycle services from Uber are Uber motor cycles. GO - JEK transportation company was established on April $13^{\text {th }}$, 2015, while GRAB was established on February 1 15, 2017, and Uber motor was established in November 2016. In this study the author took the online transportation Go - Jek, where in the application Go - Jek many types 
of services such as Go - Car, Go - Ride, Go - Food, Go - Clean, Go - Send, Go - Pulses, Go - Shop, Go - Mart, Go - Massage and others. For this study only limit the Go - Ride.

Here are several factors that influence the revenue of GO - JEK drivers, namely work, age, education level and work experience or how long the GO - JEK driver is as a driver. According to the Central Bureau of Statistics (2005) work is to do a job with a view to earning an income or profit of at least 1 hour (consecutively without interruption) in the past week. Working hours are the length of time in hours used to work from all jobs. Camerer et at (1997) in sukartini (2014: 34) states that the wage level will be responded temporarily or change by labor, where from day to day the relative wage rate is constant, but on certain days it will experience deep fluctuations count of 1 working hour period. So, in general he suggests that the more hours worked out means the more productive the work is. The more productive people devote working hours means that people will work hard to earn income. At the beginning of PT Gojek in Indonesia, drivers who worked for 16 hours a day had a lucrative income of IDR. 500,000. However, with the large number of Gojek drivers and emerging new competitors such as Grab bike, the revenue of Gojek drivers is IDR. 200,000 per day.

According to Hasyim H (2006) age can be used as a benchmark to see one's activities in work, of course the condition of the person is in good health. Age conditions that are still productive (14-65 years) make it possible that someone can work better and maximally so that their income will increase. At Gojek, those drivers who are productive age have income that is not much different, namely 3-5 million a month.

According to Todaro (2000) that there is a positive relationship between education and income to be obtained. When the education owned by the worker is high, the employee's income will increase. Higher levels of education will make a person have more and more knowledge, so it will be easier to understand the attitudes of others. Therefore, income will depend on the school years that can be completed, which is what causes inequality of income that is unfair and causes poverty. Poverty occurs a lot in the village which causes people to go to the city to find work (Syafitri, 2012).

Online transportation is an online-based transportation that uses an application in a smartphone through the Google Play Store or the app store, the way it works is the user of online transportation services or commonly referred to as the passenger will order through the online transportation application and the waiter online transportation or commonly referred to as the driver will pick up to the place where passengers and drivers will deliver it to the destination of the passenger stated in the application. Transportation has functions and benefits that are classified into several important parts. The following are the advantages of using online transportation: (1) Online transportation is easier to find, easy and fast to use. (2) Prices are more transparent because in order to order online transportation the price must be paid based on the distance to be traveled. (3) Online transportation is much safer, complete data from the drivers is directly transmitted to the passengers, starting from the number of the vehicle license plate and complete driver identity data is a security picture for passengers. (4) Online transportation is much more convenient because online transportation service companies make very strict selections on drivers and vehicles. The company also installed very high criteria on the vehicles that the drivers would use. (5) Very flexible in an era that demands high mobility today (6). Online transportation comes with various conveniences to benefit consumers and drivers. 
Table 1. Operation Variable

\begin{tabular}{|c|c|c|c|}
\hline No & $\begin{array}{c}\text { Research } \\
\text { variable }\end{array}$ & Operational Variable & $\begin{array}{c}\text { Measurement } \\
\text { Unit }\end{array}$ \\
\hline 1 & $\begin{array}{c}\text { Driver } \\
\text { Revenue (TR) }\end{array}$ & $\begin{array}{c}\text { The money that the driver receives } \\
\text { every month while working / } \\
\text { operating }\end{array}$ & $\begin{array}{c}\text { IDR } \\
\text { (ndonesian } \\
\text { Rupiahs) } \\
\text { Monthly }\end{array}$ \\
\hline 2 & Working hours & $\begin{array}{c}\text { The length of time the driver works } \\
\text { in a day }\end{array}$ & $\begin{array}{c}\text { Hours / Month } \\
\text { Ages }\end{array}$ \\
\hline 4 & $\begin{array}{c}\text { Level of } \\
\text { education }\end{array}$ & $\begin{array}{c}\text { Level of Education as a Go - Jek the field } \\
\text { driver }\end{array}$ & $\begin{array}{c}\text { Ages Year } \\
\text { Migh School/ } \\
\text { Vocational } \\
\text { High School, } \\
\text { University }\end{array}$ \\
\hline 5 & $\begin{array}{c}\text { Work } \\
\text { Experience } \\
\text { (PK) }\end{array}$ & $\begin{array}{c}\text { The duration of the driver working } \\
\text { as GO - RIDE is calculated from } \\
\text { the first time until now. } \\
\text { The duration of the driver works as } \\
\text { a driver }\end{array}$ & $\begin{array}{c}\text { Month per } \\
\text { Years }\end{array}$ \\
\hline
\end{tabular}

Source : Kumparan.com

The study entitled "Factors Affecting the Revenue of Gojek Riders in the District of Arjasa, Jember Regency" This research was conducted by Tria Fata (2002) with the aim of finding out whether the working hours, the condition of motorbikes and the length of work affect the income of motor cycle drivers. If it affects how far the effect on income. This research place is in Arjasa District, Jember Regency. The time of this study occurred in October to November.

This research uses survey method, as the object is motor cycle drivers. Data collection for samples of motor cycle drivers was carried out using the interview method. The number of respondents was 60 respondents. From this study it is known that the outpouring of working hours, the condition of motorbikes, and the length of work significantly on the income of motor cycle drivers both partially and together. The outflow of working hours on motorbike conditions and the length of work can explain the variation in income variables by $81.4 \%$, because the determination coefficient (R Square) is 0.814 . The remaining $18.6 \%$ was caused by other variations that were not included in this research model. The conclusion of this study is that the outpouring of working hours, the condition of motorbikes and the length of work have a significant effect on the income of motor cycle drivers. The relationship between working hours and income generates regression coefficient of 354,691, which means that when the motorbike condition is working for zero, the increase in working hours by one unit per month will increase the income by Indonesia Rupiahs. 354.61 per month. The relationship between working motorbike conditions and income produces regression coefficient of 0.0297, which means that at the time of working hours and working hours equal to zero, the increase in motor cycle conditions by one unit per month will increase revenue by IDR. 0.0297. The relationship between length of work and income produces a regression coefficient of 552,228 which means that when the outflow of working hours and motorbike conditions is equal to zero, the increase in working time by one unit will increase income by IDR 552,228 per month. 
The study of Sudirman and Wiwin Alwiyah (2012) was written in the Scientific Journal of Batanghari University Jambi Vol. 12 No.3 of 2012 concerning "The Influence of the Number of Passengers and Working Hours on Ojek Workers in East Jambi." In this study, motor cycle revenues in Jambi's eastern district of Jambi were influenced by two variables, the number of passengers and the number of hours worked. Ojek is an effective type of transportation service because it can be used at any time, the service is quite extensive, and the cost is relatively low. Ojek is also a major transportation for those who live in the suburbs or in rural areas. This study uses primary data which is analyzed by observation method to find out data about the influence of the number of passengers and working hours on motor cycle revenue. This study, the entire study population was a motor cycle located in Jambi Timur District, Jambi city. that is 743 people. The conclusion of this study shows that X1 (number of passengers) and X2 (working hours) can explain changes in motor cycle revenue by $54 \%$ and number of passengers (X1) and working hours (X2) have a very significant effect on motor cycle revenue with a calculated $F$ value of 57291 large of F-table value of 19.2. If the number of passengers increases, the income of a is IDR. 7202,185, and if working hours increase by 1 hour then the motor cycle revenue will increase by IDR. 2535, 868. Thus, to encourage an increase in motor cycle drivers in Jambi Regency Jambi revenue in Jambi City must encourage an increase in the number of passengers with better services.

According to Suharsimi (2010: 110) the hypothesis is a temporary answer to the problem of a research, until proven through the collected data. If the researcher has thoroughly researched the problem of his research and determined the basic assumptions, then making a temporary theory that still needs to be tested (under the truth). This is the hypothesis that researchers must think that the hypothesis can be tested.

Based on the theoretical study above, this research hypothesis can be formulated, namely as follows:

1) Working Hours, Age, Level of education and Work experience are thought to have partially influenced the revenue of Go - Jek drivers in South Tangerang.

2) Working Hours, Age, Level of education and work experience are thought to have simultaneously had an influence on the income of Go - Jek drivers in South Tangerang

\section{Research Methodology}

The research method used in this research is quantitative descriptive method. This descriptive method describes the conditions of the Go - Ride driver seen from the aspects of income, working hours, age, level of education and work experience. After knowing the condition of the driver from these aspects, then, the regression analysis in this study was used to find out how the Go - Ride driver's income relationship to working hours, age, education level and work experience. In this study the data collection method used is random sampling, which means that each member of the population has the same opportunities and opportunities to be chosen as a sample. There is no specific intervention from the researcher. Each type of random sampling has its own advantages and disadvantages. The sample in this study is:

Determination of the sample of this study using the method from the Maholtra formula (2010: 12) as follows:

$$
\begin{aligned}
\mathrm{n} & =\frac{\pi(1-\pi) \mathrm{z}^{2}}{\mathrm{D}^{2}} \\
& =\frac{0,5(1-0,5) 1,96^{2}}{(0,01)} \\
& =96,04=96
\end{aligned}
$$


Information :

$\mathrm{n}$ : number of samples

$\pi$ : proportion

D: level of precision, with a stick of confidence of $95 \%$ or $Z-1.96$

The analytical tool used in this study is a descriptive statistical analysis method and multiple linear regression analyses.

\section{Result and Discussion}

Characteristics of Respondents Based on Number of Working Hours. Working hours are the time spent by GO - RIDE drivers in South Tangerang City to find customers or orders measured in hours. The data can be seen in table 5.1. GO - RIDE drivers work more than normal working hours, which are 11-15 hours a day. This means that the GO - RIDE driver has high productivity because by working above normal working hours, drivers can get high income ranging from IDR. 2,000,000 IDR. 6,000,000 in a month.

Table 2. Number of Respondents of GO - RIDE Driver in South Tangerang City According to Working Hours per Day in 2017

\begin{tabular}{|c|c|c|c|}
\hline No & $\begin{array}{c}\text { Working Hours (In } \\
\text { Months) }\end{array}$ & Amount (people) & Percentage (\%) \\
\hline 1 & $5-10$ & 16 & 16,667 \\
\hline 2 & $11-15$ & 62 & 64,583 \\
\hline 3 & $16-20$ & 18 & 18,750 \\
\hline \multicolumn{2}{|c|}{} & 96 & 100 \\
\hline
\end{tabular}

Processed Data, 2017

Characteristics of Respondents Based on Respondents Age. Age is a life span measured by years. The fact that there are many physically retired people who are less able to work because the physical strength of old and young age is different, so it will affect the time allocated to work and will affect their income. The more a person age, the productivity will increase and will decrease at certain age points. Respondents of GO - RIDE drivers who were in the age group 30-39 years dominated the most, namely 46 people or 47.917 percent which is the prime age group. Given that the drivers work in the field, strong and strong stamina is needed. This caused an increase in the number of respondents from the young age structure to the prime age group and again experienced a decline after the prime age group.

Table 3. Age Range of Respondents

\begin{tabular}{|c|c|c|c|}
\hline No & Age (Years) & Amount & Percentages ( \%) \\
\hline 1 & $20-29$ & 39 & 40,625 \\
\hline 2 & $30-29$ & 46 & 47,917 \\
\hline 3 & $40-49$ & 8 & 8,333 \\
\hline 4 & $50+$ & 3 & 3,125 \\
\hline \multicolumn{2}{|c}{ Total } & 96 & 100 \\
\hline
\end{tabular}

Processed Data, 2017

Characteristics of Respondents Based on Level of Education. Education is very necessary in improving the welfare of the community. In this study, most of the GO - RIDE driver respondents who had education up to high school/vocational high school were 72 people or 75 percent, then the GO - RIDE driver respondents who had education up to college level were 8,333 percent. A high level of education in working as a GO - RIDE driver is necessary considering that the job as a GO 
- RIDE driver uses an online application service. By having a high education, the drivers will automatically be easier to use technology such as online application services available.

Table 4. Educational Level

\begin{tabular}{|c|c|c|}
\hline Educational Level & $\begin{array}{c}\text { Amount } \\
\text { (People) }\end{array}$ & Percentage (\%) \\
\hline Elementary & 1 & 1.042 \\
\hline Junior High School & 15 & 15,625 \\
\hline High School / Vocational High School & 72 & 75,000 \\
\hline College & 8 & 8.333 \\
\hline & 96 & 100 \\
\hline
\end{tabular}

Processed Data, 2017

Characteristics of Respondents Based on Driver Work Experience. Work experience is a period in pursuing a job that is passed by the workforce so that the workforce has experience of mastering the work. In this study, most of the GO - RIDE driver respondents worked for 11-15 months, namely 58 people or 60,417 percent. This work experience was calculated starting from GO - RIDE present in South Tangerang in February 2015. This work experience is divided into several categories, namely $1=$ less experienced (1-5 months), 2 = quite experienced $(6-10$ months $), 3=$ experienced $(11-15$ months), and $4=$ very experienced (16-20 months). On average, experienced drivers work as GO RIDE driver.

Table 5. Work Experience

\begin{tabular}{|c|c|c|}
\hline Work Experience (months) & $\begin{array}{c}\text { Numbers of } \\
\text { People }\end{array}$ & Percentages (\%) \\
\hline $1-5$ & 3 & 3,125 \\
\hline $6-10$ & 8 & 8,333 \\
\hline $11-15$ & 58 & 60.417 \\
\hline $16-20$ & 27 & 28,125 \\
\hline Total & 96 & 100 \\
\hline
\end{tabular}

Processed Data, 2017

Respondents' income. Revenue is the amount of money received by GO - RIDE drivers in South Tangerang City in units of rupiah (IDR) within one month. In this case the GO - RIDE driver has an average income ranging between IDR. 1,100,000 - IDR. 3,099,999, namely 33,333 percent or 32 respondents. When compared with the Regional Minimum Wage, which is IDR. 2,000,000, the income of GO-RTDE drivers is very promising especially with unbound working hours.

Table 6. Number of Respondents GO - RIDE Driver based on 2017 Revenue

\begin{tabular}{|c|c|c|}
\hline Revenue & Numbers of People & Percentage (\%) \\
\hline$<1.099 .999$ & 2 & 3,025 \\
\hline $1.100 .000-3.099 .999$ & 32 & 33,333 \\
\hline $3.100 .000-5.099 .999$ & 40 & 41,667 \\
\hline $5.100 .000-7.099 .999$ & 20 & 20,833 \\
\hline$>7.100 .000$ & 2 & 2,083 \\
\hline & 96 & 100 \\
\hline
\end{tabular}

Processed Data, 2017 
Effect of Working Hours on the Revenue of GO - RIDE Drivers in South Tangerang. To determine the effect of working hours on GO - RIDE driver revenue, a t test with a significant level of $10 \%$ and free degree $(n-k)$ are used which in this case can be $t$ table $=t 0.01(96-4)=1.291$. The results of the $t$ test show that the $t$ count value is $(5,293)$ greater than $t$ table $(1,291)$. So, it can be concluded that working hours have a positive and significant effect on the income of GO - RIDE drivers in South Tangerang.

Effect of Age on the Income of GO - RIDE Drivers in South Tangerang. To determine the effect of age on GO - RIDE driver revenue, a t test with a significant level of $10 \%$ and free degree (n-k) are used which in this case can be $t$ table $=t 0.01(96-4)=1.291$. The results of the $t$ test show that the $t$ count value is (-0.008) smaller than $t$ table (1.2291). So, it can be concluded that age does not affect the income of GO - RIDE drivers in South Tangerang

Effect of Education Level on RIDE Driver's Income in South Tangerang. To find out the effect of education level on GO - RIDE driver income, t-test with a significant level of $10 \%$ and free degree $(\mathrm{n}-\mathrm{k})$ are used which in this case can be $\mathrm{t}$ table $=\mathrm{t} 0.01(96-4)=1.291$. The results of the $\mathrm{t}$ test show that the $t$ count value is $(0.526)$ smaller than $t$ table (1.2291). So, it can be concluded that the level of education does not affect the income of GO - RIDE drivers in South Tangerang.

The Effect of Work Experience on the Income of GO - RIDE Drivers in South Tangerang. To find out the influence of work experience on the GO - JEK Driver's income, a t test with a significant level of $10 \%$ and free degree $(\mathrm{n}-\mathrm{k})$ are used which in this case can be t table $=\mathrm{t} 0.01(96-4)=1.291$. The results of the $t$ test show that the $t$ count value is $(3,512)$ greater than $t$ table $(1,291)$. So, it can be concluded that work experience has a positive and significant effect on the income of GO - RIDE drivers in South Tangerang.

Effect of Working Hours, Age, Level of Education, and Work Experience on the Income of GO RIDE Drivers in South Tangerang. To determine the effect of working hours, age, education level, and work experience on the GO - RIDE driver's income, an F test with a significant level of $10 \%$ and free degree $(\mathrm{k}-1)(\mathrm{nk})$ is used which in this case can F table $=\mathrm{F} 0,01(4-1) ;(96-4)=4.00$. The F Test results show that the calculated $F$ value is $(23,049)$ greater than $F$ table $(4,00)$. So, it can be concluded that working hours, age, education level, and work experience have a significant effect simultaneously on the income of GO - RIDE drivers in South Tangerang.

\section{Conclusion}

The research was carried out with the aim of assisting the Company in analyzing strategies to stay afloat amid intense competition between Online Ojek companies. The simultaneous test shows that working hours, age, level of education, and work experience have a simultaneous effect on the revenue of GO - RIDE drivers in South Tangerang.

The partial test shows that the variable working hours and work experience have a positive and significant effect on the income of GO - RIDE drivers. Drivers who devote their time to working longer will get more orders or customers so that the income earned by drivers will also increase. Likewise work experience, with the longer the drivers work as GO - RIDE drivers, they will automatically better understand the conditions in the field and better understand the conditions in the South Tangerang area.

Whereas in this case there is no influence on age and education level variables on the income of GO - RIDE drivers. Age does not affect income because drivers who are more than 40 years old can still work for 16 hours a day. The level of education, in this case, also does not affect income because drivers who have a high education do not all have high income. On average, the drivers who graduated from high school who devoted more of their working hours to earning more income were the highest of IDR. 7,750,000, compared to under graduates who only get the highest income of IDR. 6,200.000.

\section{References}

Abbas, Salim. 2003. Manajemen Transportasi. PT Grafindo Persada. Jakarta 
Adisasmita, Rahardjo. 2014. Dasar-dasar Ekonomi Transportasi. Cetakan Kedua. Graha Ilmu.

Bosworth, D., P. Dawkins, dan T. Stromback, (1996), The Economics of the Labor Market, Addison Wesley Longman Ltd., Singapore.

Dyckman, Thomas R., Roland E. Dukes, Charles J. Davis, 2002. Akuntansi Intermediate, Edisi Kesepuluh, Jilid I, Terjemahan Emil Salim. Jakarta: Erlangga

Fata, Helmi Tria. 2002. Faktor- Faktor Yang Mempengaruhi Pendapatan Tukang Ojek Di Kecamatan Arjasa Kabupaten Jember. Universitas Jember. Jember.

Fees, Reeve, Warren, dan Niswonger. 1999. Prinsip-Prinsip Akuntansi, edisi sembilan belas, Cetakan Pertama, erlangga. Jakarta

Gujarati, Damodar. 2001. Ekonometrika Dasar. Jakarta. Erlangga.

GO - JEK. 2017. Top Up GO-PAY via Driver dengan Uang Tunai. www.driver.Go - Jek.com

Hafifudin, Muhammad. 2015. Definisi Transportasi Menurut Para Ahli. www.elhavidz.blogspot.co.id

Harahap, Sofyan Syafri. 2002. Akuntansi Aktiva Tetap. Bumi Aksara: Jakarta.

http://repository.usu.ac.id/bitstream/handle/123456789/45065/Chapter\%20II.pdf?sequence=4

Kamaluddin, Rustian., 2003, Ekonomi Transportasi (Karakteristik, Teori, dan Kebijakan), Ghalia Indonesia, Jakarta. 